\title{
Screening for Executive Dysfunction with the Frontal Assessment Battery: Psychometric Properties Analysis and Representative Normative Data for Brazilian Older Adults*
}

\author{
A Bateria de Avaliação Frontal para o Rastreio de Disfunção Executiva: Análise de Propriedades \\ Psicométricas e Dados Normativos Representativos para Idosos Brasileiros
}

\author{
Jonas Jardim de Paula ${ }^{\mathrm{I}, \mathrm{II}}$ \\ Samara Melo Moura ${ }^{\text {III }}$ \\ Matheus Bortolosso Bocardi ${ }^{\mathrm{IIV}}$ \\ Edgar Nunes de Moraes ${ }^{\mathrm{V}}$ \\ Leandro Fernandes Malloy-Diniz ${ }^{\mathrm{III}, \mathrm{VI}}$ \\ Vitor Geraldi Haase $\mathrm{IIIIV}^{\mathrm{IV}}$
}

\begin{abstract}
Introduction: The Frontal Assessment Battery (FAB) is a for the assessment of executive functions. We investigated its validity and reliability and proposed normative data in a representative sample of older adults. Method: 391 healthy elderly subjects and 93 Alzheimer's disease (AD) patients performed the FAB. Internal consistency, convergent correlations, ROC curve and logistic regression were used to assess its psychometric properties. Results: We found good internal consistency, significant correlations with other tests and moderate accuracy (64\%) for AD diagnosis. The use of specific subtests increased diagnostic potential (75\%). Normative data stratified by age and education were proposed. Conclusion: The FAB showed adequate psychometric properties. The normative values stratified by age and education can improve its clinical use for neuropsychological assessment.
\end{abstract}

Keywords: Frontal Assessment Battery; normative data; psychometric properties; Alzheimer's disease.

Resumo

Introduçáo: A Bateria de Avaliaçáo Frontal (BAF) é um teste de rastreio para o exame das funçóes executivas. Investigou-se sua validade e fidedignidade e propuseram-se dados normativos em uma amostra representativa de idosos. Método: 391 idosos saudáveis e 93 pacientes diagnosticados com doença de Alzheimer (DA) realizaram a FAB. Consistência interna, correlaçóes convergentes, curva ROC e regressão logística compuseram a avaliação das propriedades psicométricas do teste. Resultados: Foi encontrada boa consistência interna, correlaçóes significativas com outros testes e acurácia moderada (64\%) para o diagnóstico de DA. O uso de subtestes específicos aumentou o potencial diagnóstico (75\%). Normatização estratificada por idade e escolaridade foi proposta. Conclusão: A BAF apresentou propriedades psicométricas adequadas. Os valores normativos estratificados por idade e escolaridade podem melhorar o uso desse instrumento no exame neuropsicológico.

Palavras-chave: Bateria de Avaliação Frontal; normatização; propriedades psicométricas; doença de Alzheimer.

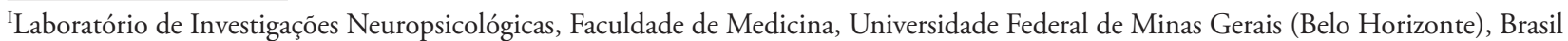
IIInstituto Nacional de Ciências e Tecnologia de Medicina Molecular, Faculdade de Medicina, Universidade Federal de Minas Gerais (Belo Horizonte), Brasil

IIILaboratório de Neuropsicologia do Desenvolvimento, Faculdade de Filosofia e Ciências Humanas, Universidade Federal de Minas Gerais (Belo Horizonte), Brasil

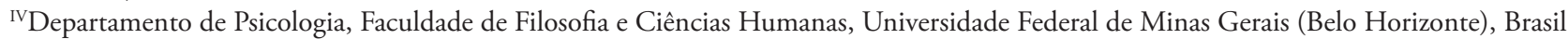

v Departamento de Clínica Médica, Faculdade de Medicina, Universidade Federal de Minas Gerais (Belo Horizonte), Brasil

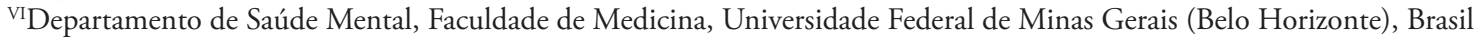

The Frontal Assessment Battery (FAB) consists of six quick tests designed to assess frontal-executive functions. It was proposed by Dubois, Slachevsky, Litvan \& Pillon (2000) as a short bedside cognitive battery for patients with frontal lobe dysfunction. Two Brazilian versions were proposed, one by Beato, Nitrini, Formigoni \& Caramelli (2007) with preliminary data for the administration in healthy elderly patients and subsequent norms (Beato et al., 2012) and the other, slightly different, exposed in a dissertation, in which the validity and normative values of three screening tests including the FAB were developed in a representative sample of a Brazilian city (Moura, 2008). The test has been used in different clinical populations that usually present frontal lobe dysfunction, such as frontotemporal dementia, Parkinson's disease dementia, corticobasal degeneration, progressive supranuclear palsy, and multiple system atrophy (Dubois et al., 2000). Some studies have proposed its use for the differential diagnosis of Alzheimer's disease (AD) from frontotemporal dementia and found good 
evidence of criterion validity (Slachevsky et al., 2004); however, these findings were inconsistent (Castiglione et al., 2008).

Executive impairments are a common finding in mild AD (Baudic et al., 2006) and are usually associated with pronounced episodic memory impairment. Nagata et al. (2010), in a study using the $\mathrm{FAB}$ in $\mathrm{AD}$ and mild cognitive impairment patients, suggest that specific components of the battery (more specifically, the Go, No go task) may be altered in AD. This task demands the integration of basal ganglia and prefrontal cortex, specially the anterior cingulate and fronto-orbital circuits (Langenecker et al., 2007). Nagata et al. (2010) argue that the hippocampal atrophy of $\mathrm{AD}$ patients may secondarily disrupt the connections of basal ganglia and the prefrontal cortex, underlying the executive dysfunction observed in some $\mathrm{AD}$ patients.

Based on a literature review performed in Pubmed (with the terms "Frontal Assessment Battery" and "Brazil") and SciELO ("Frontal Assessment Battery" or "Bateria de Avaliação Frontal") databases, the FAB has been used in different contexts in Brazil (Table 1). After the exclusion of review papers, case reports and studies published in languages different from English or Portuguese, the review showed that the test was applied in the assessment of Parkinson's and Huntington's disease, alcohol and cocaine users and other neurological patients. Only four Brazilian studies found in this review used the FAB in $\mathrm{AD}$ patients (Pedroso et al., 2012; de Paula et al., 2012a; de Paula, Miranda, Moraes \& Malloy-Diniz, in press; de Paula \& Malloy-Diniz, 2013). Only two studies aimed at the performance of healthy older adults in (Beato et al., 2007; 2012). They found significant influences of age and education on test performance in the first study (2007); however, in a greater sample (2012), only education was associated with FAB scores. Also, no study assessed the role of the FAB in the diagnosis of AD.

The objectives of this study were (1) analyze the internal consistency, and the effects of age, schooling and gender on FAB performance, (2) provide normative data for Brazilian older adults for the test in a representative sample; (3) investigate the criterion validity of the $\mathrm{FAB}$ in diagnosing $\mathrm{AD}$. We hypothesize that the FAB will present good internal consistency, a significant effect of age and education on test scores and the test might be useful for the diagnosis of $\mathrm{AD}$.

\section{Methods}

\section{Participants}

Based on the Brazilian Census (IBGE, 2002), the prevalence of elderly subjects in Belo Horizonte (one of the largest cities of Brazil) is 9.14\%. Using the equation of Portney \& Atkins (2000) for sample size and establishing a confidence interval of $95 \%$ with maximum error of $3 \%$, the required sample for a representative populational study was of 350 participants. For this study, 391 healthy older adults were assessed. The total sample was divided into smaller groups based on age, schooling and gender distribution according to Belo Horizonte city demographic characteristics. The participants were invited from community centers, churches, retired people associations, local announcements or were relatives of the clinical group participants. The exclusion criteria were severe perceptual-motor deficits, presence of neuropsychiatric disorders, history of alcohol or other drug abuse, neurological damage, neurosurgery, severe cardiac, hepatic or renal insufficiency, cardiac arrest in the past five years, acute confusional status and noncontrolled diabetes or hypertension. These criteria were investigated by a structured interview conducted in the time of assessment.

For the AD group, 93 patients were invited from a public secondary health care unit specialized in gerontology. Diagnoses were performed by a multidisciplinary board composed by at least one geriatrician and one clinical neuropsychologist, based on the DSM-IV (American Psychiatric Association, 1994), NINCDS-ADRDA (McKhann et al., 1984) and NINDS-AIREN (Román et al., 1993) criteria. No AD patients presented history of other neurological disorder or psychotic illness. All $\mathrm{AD}$ patients followed their treatment plans, which included taking anticholinesterase inhibitors, and were free from typical or atypical antipsychotic drugs.

\section{Statistical Analysis}

The internal consistency of the FAB was assessed by Cronbach's Alpha. For this analysis, 18 variables of the FAB were used, three for each subtest. The influence of age, education and gender on FAB total score was assessed by a multiple linear regression model. The model was built in SPSS 17.00 (SPSS Inc., 2009) by the enter method. For each variable, the unstandardized $(\beta)$ and standardized $(S \beta)$ coefficients, as well as the standard error (SE) and significance 
Table 1. Brazilian studies using the Frontal Assessment Battery

\begin{tabular}{|c|c|c|c|}
\hline Study & Objective & Participants & Results \\
\hline $\begin{array}{l}\text { Cunha, Nicastri, } \\
\text { Gomes, Moino, } \\
\text { \& Peluso (2004) }\end{array}$ & $\begin{array}{l}\text { Assess the performance } \\
\text { of crack-cocaine } \\
\text { users in the second } \\
\text { week of abstinence }\end{array}$ & $\begin{array}{l}15 \text { crack-cocaine users } \\
\text { and } 15 \text { healthy adults }\end{array}$ & $\begin{array}{l}\text { Significant differences in } \\
\text { FAB score }(\mathrm{d}=1.11)\end{array}$ \\
\hline $\begin{array}{l}\text { Beato, Nitrini, } \\
\text { Formigoni, \& } \\
\text { Caramelli (2007) }\end{array}$ & $\begin{array}{l}\text { Evaluate performance } \\
\text { of normal elderly } \\
\text { and test correlations } \\
\text { with age, schooling } \\
\text { and MMSE }\end{array}$ & $\begin{array}{l}48 \text { cognitively } \\
\text { intact elderly }\end{array}$ & $\begin{array}{l}\text { Mean score of } 13.0(\mathrm{SD}=2.3) \text {, } \\
\text { ranging from } 7-18 . \text { Significant } \\
\text { correlations with Education } \\
(0.366) \text { and MMSE }(0.458)\end{array}$ \\
\hline $\begin{array}{l}\text { Moura, \& } \\
\text { Haase (2008) }\end{array}$ & $\begin{array}{l}\text { Evaluate the } \\
\text { psychometric } \\
\text { properties of a memory } \\
\text { screening test in } \\
\text { Brazilian older adults. }\end{array}$ & $\begin{array}{l}350 \text { healthy } \\
\text { elderly patients. }\end{array}$ & $\begin{array}{l}\text { The FAB showed significant } \\
\text { correlations with the Three Words- } \\
\text { Three Shapes test }(\mathrm{r}=0.460,<0.05)\end{array}$ \\
\hline $\begin{array}{l}\text { Rodrigues } \\
\text { et al. (2009) }\end{array}$ & $\begin{array}{l}\text { Assess the validity of } \\
\text { the FAB for patients } \\
\text { with Huntington } \\
\text { Disease. }\end{array}$ & $\begin{array}{l}41 \text { patients with } \\
\text { Huntington Disease } \\
\text { and } 53 \text { matched } \\
\text { controls } \\
\text { (age } 18-72 \text { years) }\end{array}$ & $\begin{array}{l}\text { Significant differences in total score } \\
(\mathrm{d}=1.63) \text {. Influences of education } \\
\text { were found. The FAB shows good } \\
\text { internal consistency }(>0.75) \text {, strong } \\
\text { correlations with MMSE scores and } \\
\text { moderate AUC when discriminating } \\
\text { clinical and control groups }(0.840)\end{array}$ \\
\hline Dias et al. (2009) & $\begin{array}{l}\text { Assess the frontal lobe } \\
\text { function in patients of } \\
\text { Blepharospasm when } \\
\text { compared with patients } \\
\text { of hemifacial spasm. }\end{array}$ & $\begin{array}{l}22 \text { Blepharospasm } \\
\text { patients (mean age } \\
\text { of } 61.5 \text { year) and } \\
29 \text { patients with } \\
\text { hemifacial spasm } \\
\text { (mean age } 60.5 \text { years) }\end{array}$ & $\begin{array}{l}\text { No differences in FAB total score. } \\
\text { The total score correlated negatively } \\
\text { with age }(\text { rho }=-0.348) \text { and positively } \\
\text { with educational level }(\mathrm{rho}=0.516) \\
\text { and MMSE }(\mathrm{rho}=0.627) .\end{array}$ \\
\hline $\begin{array}{l}\text { Zago-Gomes } \\
\text { \& Nakamura- } \\
\text { Palacios (2009) }\end{array}$ & $\begin{array}{l}\text { Evaluate the frontal } \\
\text { lobe functions and } \\
\text { mental state in } \\
\text { patients with alcoholic } \\
\text { dependence. }\end{array}$ & $\begin{array}{l}170 \text { patients with } \\
\text { alcoholism and } 40 \\
\text { controls matched } \\
\text { by age }(20-76) .\end{array}$ & $\begin{array}{l}\text { Alcoholism patients had significant } \\
\text { lower scores than controls. }\end{array}$ \\
\hline $\begin{array}{l}\text { Domingues, } \\
\text { Mendonça, } \\
\text { Laranjeira \& } \\
\text { Nakamura- } \\
\text { Palacios (2009) }\end{array}$ & $\begin{array}{l}\text { Analyze the possible } \\
\text { association of FAB } \\
\text { total scores and blood } \\
\text { alcohol concentration } \\
\text { in drivers. }\end{array}$ & $\begin{array}{l}389 \text { drivers } \\
\text { (age } 20-40)\end{array}$ & $\begin{array}{l}\text { Drivers with alcohol blood } \\
\text { concentrations superior to the } \\
\text { cut off }(0.06 \%) \text { presented lower } \\
\text { scores than those below it. }\end{array}$ \\
\hline $\begin{array}{l}\text { Cunha, Nicastri, } \\
\text { Andrade \& } \\
\text { Bolla }(2010)\end{array}$ & $\begin{array}{l}\text { Evaluate cognitive } \\
\text { performance in } \\
\text { drug abusers. }\end{array}$ & $\begin{array}{l}30 \text { patients with } \\
\text { cocaine use and } 32 \\
\text { healthy controls. } \\
\text { (Mean age } 27 \text { years). }\end{array}$ & $\begin{array}{l}\text { Significant differences in FAB total } \\
\text { scores were found }(\mathrm{d}=1.05) \text {. }\end{array}$ \\
\hline $\begin{array}{l}\text { Kummer, Cardoso, } \\
\text { \& Teixeira (2009a) }\end{array}$ & $\begin{array}{l}\text { Analyze the frequency } \\
\text { of suicidal ideation } \\
\text { in patients with } \\
\text { Parkinson's disease. }\end{array}$ & $\begin{array}{l}90 \text { Parkinson's disease } \\
\text { patients, } 13 \text { with } \\
\text { suicide ideation (mean } \\
\text { age of } 51 \text { years) and } \\
77 \text { without (mean } \\
\text { age of } 57 \text { years). }\end{array}$ & $\begin{array}{l}\text { No differences in FAB total score } \\
\text { between the two groups. The test } \\
\text { did not show significance as a } \\
\text { predictor of suicide attempts. }\end{array}$ \\
\hline
\end{tabular}


Table 1. Continuation...

\begin{tabular}{|c|c|c|c|}
\hline Study & Objective & Participants & Results \\
\hline $\begin{array}{l}\text { Kummer et al. } \\
(2009)\end{array}$ & $\begin{array}{l}\text { Assess the performance } \\
\text { of low and high } \\
\text { educational non } \\
\text { demented Parkinson's } \\
\text { disease patients on the } \\
\text { FAB and the influence of } \\
\text { depression on test scores. }\end{array}$ & $\begin{array}{l}82 \text { Parkinson’s } \\
\text { disease patients }\end{array}$ & $\begin{array}{l}\text { The group of higher education } \\
\text { performed better than the lower } \\
\text { education one }(\mathrm{d}=1.02) \text {. Correlations } \\
\text { with age }(-0.388) \text {, education }(0.591) \text {, } \\
\text { depressive symptoms }(-0.260) \text { and } \\
\text { MMSE }(0.651) \text { were found. }\end{array}$ \\
\hline $\begin{array}{l}\text { Kummer, Cardoso } \\
\& \text { Teixeira (2009b) }\end{array}$ & $\begin{array}{l}\text { Assess the frequency } \\
\text { of loss of libido and its } \\
\text { relation to neurological } \\
\text { symptoms, anxiety, } \\
\text { fatigue and cognition } \\
\text { in patients with } \\
\text { Parkinson's disease. }\end{array}$ & $\begin{array}{l}90 \text { patients with } \\
\text { Parkinson's disease } \\
\text { (mean age of } 55 \text { years) }\end{array}$ & $\begin{array}{l}\text { Lower scores on FAB were associated } \\
\text { with decreased interest in sex. }\end{array}$ \\
\hline Fontes et al. (2011) & $\begin{array}{l}\text { Assess the cognitive } \\
\text { function of chronic } \\
\text { cannabis users. }\end{array}$ & $\begin{array}{l}107 \text { abstinent } \\
\text { cannabis users and } 44 \\
\text { matched controls. }\end{array}$ & $\begin{array}{l}\text { Poor performance of chronic } \\
\text { cannabis users when compared } \\
\text { with normal controls. }\end{array}$ \\
\hline Pedroso et al. (2012) & $\begin{array}{l}\text { Analyze the effects of } \\
\text { a program of physical } \\
\text { activity in executive } \\
\text { functioning, balance } \\
\text { and frequency of falls } \\
\text { in patients with AD. }\end{array}$ & $\begin{array}{l}21 \text { patients with } \mathrm{AD} \\
\text { (mean age } 78.3 \text { years) }\end{array}$ & $\begin{array}{l}\text { Participants of the physical activity } \\
\text { program had an increase on FAB } \\
\text { total score (Pretest mean }=9 \text {, posttest } \\
\text { mean }=14) \text {, while no effect was } \\
\text { seen in the control group. Positive } \\
\text { correlations of FAB with balance and } \\
\text { motor measures }(r=-0.67 \text { and } r=-0.64) \text {. }\end{array}$ \\
\hline Beato et al. (2012) & $\begin{array}{l}\text { Development of } \\
\text { population norms } \\
\text { for the Brazilian } \\
\text { version of the FAB. }\end{array}$ & $\begin{array}{l}275 \text { healthy } \\
\text { older adults. }\end{array}$ & $\begin{array}{l}\text { Education was the only variable } \\
\text { correlated with FAB performance. }\end{array}$ \\
\hline $\begin{array}{l}\text { de Paula et al. } \\
\text { (2012a) }\end{array}$ & $\begin{array}{l}\text { Validate two versions of } \\
\text { the Tower of London } \\
\text { Test for diagnosing } \\
\text { mild AD and Mild } \\
\text { Cognitive Impairment. }\end{array}$ & $\begin{array}{l}60 \text { mild } \mathrm{AD} \text { patients } \\
\text { and } 60 \text { Amnestic } \\
\text { Mild Cognitive } \\
\text { Impairment Patients }\end{array}$ & $\begin{array}{l}\text { Significant correlations between } \\
\text { FAB and two versions of the Tower } \\
\text { of London }(\mathrm{r}=0.32 \text { and } \mathrm{r}=0.46) \text {. } \\
\text { Differences were found between FAB } \\
\text { performance in Mild AD and Mild } \\
\text { Cognitive Impairment }(\mathrm{d}=0.83) \text {. } \\
\text { Multiple Domain Amnestic Mild } \\
\text { Cognitive Impairment performed } \\
\text { worse than Single Domain }(\mathrm{d}=1.14)\end{array}$ \\
\hline $\begin{array}{l}\text { de Paula \& Malloy- } \\
\text { Diniz (2013) }\end{array}$ & $\begin{array}{l}\text { Evaluate the ecological } \\
\text { validity of executive } \\
\text { functions and } \\
\text { episodic memory in } \\
\text { elderly patients. }\end{array}$ & $\begin{array}{l}76 \text { patients diagnosed } \\
\text { with } \mathrm{AD} \text { and } 42 \\
\text { patients diagnosed } \\
\text { with Mild Cognitive } \\
\text { Impairment. }\end{array}$ & $\begin{array}{l}\text { The FAB loaded on a component } \\
\text { (by factor analysis) related to } \\
\text { general executive functioning, and } \\
\text { predicted about } 30 \% \text { of variance } \\
\text { in Activities of Daily Living. }\end{array}$ \\
\hline $\begin{array}{l}\text { de Paula, Miranda, } \\
\text { Moraes, \& Malloy- } \\
\text { Diniz (in press) }\end{array}$ & $\begin{array}{l}\text { Investigate what } \\
\text { cognitive constructs } \\
\text { underlie the } \\
\text { performance on the } \\
\text { Clock Drawing Test }\end{array}$ & $\begin{array}{l}57 \text { normal older } \\
\text { adults, } 53 \text { amnestic } \\
\text { Mild Cognitive } \\
\text { Impairment } \\
\text { patients and } 60 \\
\text { mild Alzheimer's } \\
\text { disease patients. }\end{array}$ & $\begin{array}{l}\text { The FAB was the strongest cognitive } \\
\text { predictor of the Clock Drawing } \\
\text { Test performance. Normal aging } \\
\text { participants performed better than } \\
\text { amnestic Mild Cognitive Impairment } \\
\text { and those better than Alzheimer's } \\
\text { disease patients on the FAB. }\end{array}$ \\
\hline
\end{tabular}

FAB: Frontal Assessment Battery; MMSE: Mini-Mental State Exam; AD: Alzheimer's disease. 
were calculated. The correlation between Frontal Assessment Battery (FAB) and the Mini-Mental State Exam (MMSE) total score was performed by partial correlations controlling for the socio-demographic variables related to test performance.

For determining age and formal education intervals for normative data, Receiver Operator Characteristics (ROC) curve analysis was performed. For each formal education year, a ROC curve was calculated and compared to the other ones (e.g. $0 \times 1-15$, $1 \times$ (0 and 2-15) and so on). Based on Swets (1998) guidelines for ROC curve power effects interpretation, results were classified as weak (0.50-0.69), moderate (0.70-0.89) and large (0.90-1.00). After this procedure, the subgroups for normatization were defined when the lower bound of the confidence interval (95\%) showed a moderate effect on ROC analysis. The same procedure was performed for each age group. After the subgroups (age versus education) definition, the 25, 50 and 75 percentiles were calculated.

For assessing FAB criterion related validity, we studied the performance of 93 mild $\mathrm{AD}$ patients and compared to 93 normal controls (NC) from the normative data sample. The NC participants were selected matching as much as possible the demographic characteristics of AD patients. The AD and NC comparison in age, education, MMSE, FAB total score and specific battery components were performed by Mann-Whitney tests, and effect sizes estimated by the $r$ statistic $\left(\mathrm{r}=\mathrm{Z} / \sqrt{\mathrm{n}}_{\mathrm{n}}\right)$, where 0.1 is a small effect, 0.3, a moderate effect and 0.5, a large effect. Gender frequency was compared by chi-square test. For the assessment of FAB criterion validity for $\mathrm{AD}$, two independent procedures were adopted. First, ROC curve analysis was performed with FAB total score. Sensitivity and specificity were calculated, and the cutoff scores which offered the best balance between these two variables were suggested. Secondly, two binary logistic regression models were built. The first had the FAB total score as a predictor of group classification (controls versus $\mathrm{AD}$ ). The second model tested the contribution of specific subtests for this purpose, and was built entering the six subtests.

\section{Results}

Considering the $18 \mathrm{FAB}$ items (3 for each component of the battery), the test presented moderate to high internal consistency in the $\mathrm{NC}$ (0.79) and $\mathrm{AD}$ group (0.87). The linear regression model was significant $(F(4,350)=56.760, p<0.001$,
$\left.\mathrm{R}^{2}=0.325\right)$. Influences of Age $(\beta=-0.83, S \beta=-0.209$, $\mathrm{SE}=0.018, \quad \mathrm{p}<0.001)$ and Education $(\beta=0.351$, $S \beta=0.351, \quad S E=0.031, \quad p<0.001)$ were significant, but gender influence $(\beta=-0.429, \quad S \beta=-0.053$, $\mathrm{SE}=0.366, \mathrm{p}=0.242)$ was not. The FAB total score correlated with the MMSE $(r=0.675, \mathrm{p}<0.001)$. After discounting effects of age and education (using partial correlations), the two cognitive measures still showed a moderate association $(\mathrm{r}=0.508, \mathrm{p}<0.001)$.

The normatization sample mean age and education were $72.50(\mathrm{SD}=8.28,60-99)$ and 6.51 $(\mathrm{SD}=4.86,0-18)$, respectively. There were more female than male participants (19 versus $81 \%$ ). By means of ROC analysis, four education and two age groups were defined for normative data: illiterate, low education (1-2 years), medium education (3-14 years) and high education ( $>14$ years). Considering age, the sample was divided into two groups: $60-79$ years and 80 or more years. FAB total score 25,50 and 75 percentiles were then defined for each combined (age versus education) group (Table 2). Results below the equivalent score of the 25 percentile may be considered of clinical relevance.

Table 2. Normative values for the FAB in older adults.

\begin{tabular}{llcc}
\hline & & \multicolumn{2}{c}{ Age group } \\
\hline & & $\mathbf{6 0 - 7 9}$ & $\mathbf{8 0 +}$ \\
\hline Illiterate & & $\mathrm{n}=30$ & $\mathrm{n}=18$ \\
& Mean (SD) & $8.06(2.59)$ & $7.00(2.21)$ \\
& $25 \mathrm{Pc}$. & 7.00 & 5.00 \\
& 50 Pc. & 9.00 & 7.00 \\
& 75 Pc. & 10.00 & 8.00 \\
\hline Low & & $\mathrm{n}=19$ & $\mathrm{n}=18$ \\
education & Mean (SD) & $11.00(2.79)$ & $9.18(2.93)$ \\
(1-2 years) & 25 Pc. & 10.00 & 7.00 \\
& 50 Pc. & 10.00 & 10.00 \\
& 75 Pc. & 13.00 & 12.00 \\
\hline Moderate & & $\mathrm{n}=200$ & $\mathrm{n}=54$ \\
education & Mean (SD) & $12.75(3.38)$ & $10.28(3.69)$ \\
(3-14 years) & 25 Pc. & 11.00 & 8.00 \\
& 50 Pc. & 13.00 & 12.00 \\
& 75 Pc. & 15.00 & 13.00 \\
\hline High & & $\mathrm{n}=32$ & $\mathrm{n}=20$ \\
education & Mean (SD) & $15.50(2.00)$ & $16.75(2.59)$ \\
(>14 years) & 25 Pc. & 14.00 & 11.00 \\
& 50 Pc. & 16.00 & 15.00 \\
& 75 Pc. & 17.00 & 16.00 \\
\hline
\end{tabular}

FAB: Frontal Assessment Battery; SD: standard deviation; Pc.: percentile. 
Table 3. Comparisons between Healthy Controls and mild Alzheimer's disease patients

\begin{tabular}{lccccccc}
\hline \multirow{2}{*}{$\begin{array}{c}\text { Sociodemographic and } \\
\text { cognitive variables }\end{array}$} & \multicolumn{2}{c}{ Controls } & \multicolumn{2}{c}{ Mild AD } & \multicolumn{2}{c}{ Group comparisons } \\
\cline { 2 - 8 } & Median & SE & Median & SE & MW & Z & r \\
\hline Age & 76 & 0.61 & 75 & 0.69 & 3715.00 & -1.66 & -0.12 \\
Formal education & 4 & 0.30 & 4 & 0.36 & 4698.00 & 1.03 & -0.08 \\
MMSE & 25 & 0.37 & 21 & 0.41 & 2336.00 & $-5.43^{* *}$ & -0.40 \\
FAB - Total Score & 11 & 0.29 & 9 & 0.33 & 1650.00 & $-4.58^{* *}$ & -0.34 \\
Similarities & 2 & 0.11 & 1 & 0.12 & 3589.50 & $-2.07^{*}$ & -0.15 \\
Verbal fluency & 2 & 0.10 & 2 & 0.09 & 4788.00 & 1.34 & -0.10 \\
Motor sequence & 2 & 0.10 & 1 & 0.09 & 2390.00 & $-5.68^{* *}$ & -0.42 \\
Conflicting instructions & 2 & 0.11 & 1 & 0.13 & 2703.00 & $-4.60^{* *}$ & -0.34 \\
Go, No go & 1 & 0.11 & 0 & 0.10 & 3735.50 & -1.74 & -0.13 \\
Prehension behavior & 3 & 0.00 & 3 & 0.03 & 4185.00 & -1.74 & -0.13 \\
\hline
\end{tabular}

AD: Alzheimer's disease; SE: standard error; MMSE: Mini-Mental State Exam; FAB: Frontal Assessment Battery; ${ }^{*} \mathrm{p}<0.05 ;{ }^{* *} \mathrm{p}<0.001$.

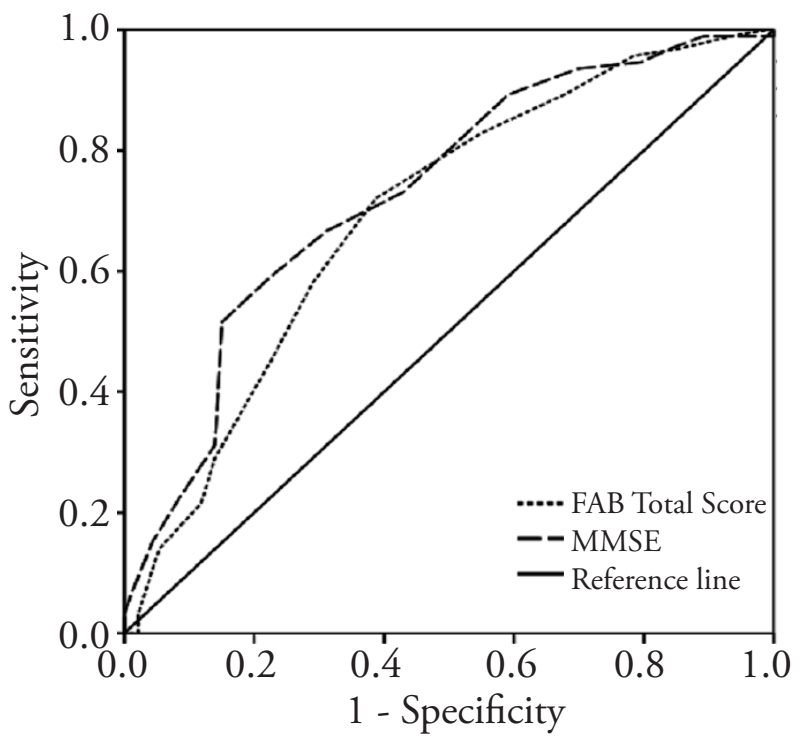

Figure 1. ROC Curve discriminating normal aging and Mild Alzheimer's disease with the Frontal Assessment Battery (FAB) and the Mini-Mental State Exam (MMSE)

The NC and AD comparisons indicate no differences in age, formal education or proportion between men and women (all $\mathrm{p}>0.05$ ). In cognitive performance (results on Table 3), differences were found in the MMSE, FAB total score and the subtests Similarities, Motor Sequence, Conflicting Instructions and Prehension Behavior, with moderate effect sizes for these comparisons except for Similarities, which showed a small effect.

ROC curve analysis is shown on Figure 1. The area under the curve of the FAB was 0.70 , very similar to the MMSE on this population (0.73). The cutoff 9 (case)/10(non-case) showed the best ratio between sensitivity (0.720) and specificity (0.61). The area can be considered moderate.

The first Binary Logistic Regression model, containing FAB total score was significant $\left(\chi^{2}=19.96\right.$, $\left.\mathrm{p}<0.001, \mathrm{R}^{2}=0.14\right)$, and improved participants' classification from chance $(50 \%)$ to $64 \%$. The regression coefficient $(\beta)$ was $-0.223, \chi^{2}=17.43$, $\mathrm{p}<0.001$. A second model tested the contribution of specific subtests for participants' classification. The second model was significant $\left(\chi^{2}=57.57, \mathrm{p}<0.001\right.$. $\left.\mathrm{R}^{2}=0.35\right)$ and improved participants' classification to $75 \%$. The subtests Verbal Fluency $\left(\chi^{2}=7.94, \beta=0.575\right.$, $\mathrm{p}=0.005)$, Motor Sequence $\left(\chi^{2}=18.99, \beta=-0.864\right.$, $\mathrm{p}<0.001)$ and Conflicting Instructions $\left(\chi^{2}=9.83\right.$, $\beta=-0.497, p=0.002)$ were significant and the other three subtests were not (all $\mathrm{p}>0.05$ ). When the two models were compared, the use of only three FAB subtests improved the classification in $11 \%$, compared to the total score, being a more accurate model $(p<0.001)$. These results suggest a more specific pattern of impairment for $\mathrm{AD}$ patients.

\section{Discussion}

FAB total score was significantly affected by age and formal education, but not by gender. The influence of education on test performance was particularly relevant. On this normatization sample, the 50 percentile of illiterate and low educated groups is below the usually adopted cut off score for frontal lobe dysfunction of 10/11 (case/non case) (Kim et al., 2010). The effect of education on test performance is a relevant factor for clinical use and was found in two previous 
Brazilian studies using the FAB (Beato et al., 2007; 2012). The normative study conducted by Beato et al. (2012) stratified FAB performance on four groups based on education: $1-3,4-7,8-11$ and 12 or more years, but had no age stratification, a different pattern than the one found in our study. However, differences in participants' characteristics may have contributed for the discrepancies, since Beato et al. (2012) studied younger participants (starting at 44 years) and did not assess illiterate people. Our normative data in this sense are complementary to those previously published and the stratification of the groups by the age variable may contribute for the neuropsychological assessment, since executive/frontal lobe functions show a more pronounced decline after the seventy years (Salthouse, 2012).

Considering the criterion validity aspects of the FAB, ourstudy shows that, besides significant differences have been found between healthy older adults and the $\mathrm{AD}$ group in the $\mathrm{FAB}$ total score, specific subtests are more accurate for a differential diagnosis. Considering a screening neuropsychological test, the $11 \%$ difference on accuracy obtained by the three significant subtests for detection of $\mathrm{AD}$ is an important finding. The results suggest a more specific pattern of executive/ frontal functions impairment by these patients. Verbal Fluency tests are commonly impaired in $\mathrm{AD}$ patients, even in the mild stage of the dementia, as suggested by a meta-analysis about this issue (Henry, Crawford \& Phillips, 2004). Usually, semantic aspects of Verbal Fluency are more impaired in this population when compared to phonemic aspects, which may explain the moderate effect sizes when the two groups were compared in our study (Henry, Crawford, \& Phillips, 2004). The motor sequence component of the FAB was firstly designed by Luria (1962) for the detection of frontal lobe dysfunction, based on his experience with frontal lesion patients. Studies of functional neuroimaging associate the frontal (more related to the execution and monitoring of the sequence) and parietal (related to the motor planning) lobes with test execution (Umetsu et al., 2002), and cortical atrophy and glucose hypometabolism in these areas are a common finding in $\mathrm{AD}$, according to a meta-analysis of neuroimage studies (Schroeter, Stein, Maslowski, \& Neumann 2009), which may contribute for the motor sequence subtest role on differential diagnosis. Finally, the third subtest which significantly contributed for the differential diagnosis of normal aging and
$\mathrm{AD}$ was the Conflict Instructions test, designed to assess selective attention, a concept very close to the definition of inhibitory control (Posner \& Rothbart, 2007). This cognitive process involves the inhibition of a prominent, intuitive and automatic cognitive process in favor of a more controlled one. This might be an earlier marker of cognitive dysfunction in $\mathrm{AD}$, even in its prodromal states (Balota et al., 2010; de Paula et al., 2011;2012a; 2012b) and is closely related to the anterior cingulated cortex activity (Hayward, Goodwin \& Harmer, 2004), an area which is also affected by AD pathology in its earlier stages (Schroeter et al., 2009).

The accuracy of the FAB for diagnosing $\mathrm{AD}$ was only moderate in the present study. The FAB is usually associated with general measures of cognitive functioning, such as the Dementia Rating Scale (Dubois et al., 2000) and the MMSE (Beato et al., 2007), with moderate or large effect sizes. The cognitive impairment in mild $\mathrm{AD}$ is usually not very pronounced, and is more expressive on episodic memory deficits, which may explain the moderate accuracy of the FAB alone in diagnosing AD. However, as an executive/frontal lobe measure, it may contribute to establish the cognitive profile of a suspected $\mathrm{AD}$ patient.

The executive functions impairment in $\mathrm{AD}$ patients is usually less intense than the one found in patients with more pronounced frontal lobe damage, such as frontotemporal dementia, focal brain lesions and subcortical dementias (Liscic, Storandt, Cairns \& Morris, 2007; Boban, Malojcic, Mimica, Vukovic \& Zrilic, 2012; Yoon et al., 2013; Saur et al., 2012). Since the FAB is a screening test, its accuracy for detecting executive impairment in $\mathrm{AD}$ patients may be limited, and that evaluation should be complemented with neuropsychological tests designed for the assessment of more specific components of executive functioning, such as inhibitory control (Balota et al., 2010; de Paula et al., 2012b), planning (de Paula et al., 2012a), cognitive shifting (Hamdan, \& Hamdan, 2009), decision making (Malloy-Diniz et al., 2008), working memory (Wood, Carvalho, Neves \& Haase, 2001) and ecological executive performance (Pereira, Oliveira, Diniz, Forlenza \& Yassuda, 2012).

\section{Conclusion}

The Brazilian elderly population is composed by a large portion of illiterate people. Those with only few years of formal education (1 to 4) are 
usually classified as functional illiterate (they can sign their own name but cannot fully read and comprehend a simple text). In the past years, some effort has been done for improving the assessment of executive functions in this population, using neuropsychological tests less influenced by formal education (de Paula et al., 2011; 2012a; 2012b) or improving normative data for more traditional tests (Machado et al., 2009; Beato et al., 2012). The current study, adopting a populational representative methodology and including older adults with very low or even non-formal education, may contribute for this issue, establishing normative values for the $\mathrm{FAB}$ and testing its criterion related validity for $\mathrm{AD}$.

\section{References}

American Psychiatric Association [APA]. (1994). Diagnostic and statistical manual of mental disorders ( $4^{\text {th }}$ ed.). Washington, DC: Author.

Balota, D. A., Tse, C. S., Hutchison, K. A., Spieler, D. H., Duchek, J. M., \& Morris, J. C. (2010). Predicting conversion to dementia of the Alzheimer's type in a healthy control sample: The power of errors in Stroop color naming. Psychology \& Aging, 25(1), 208-218.

Baudic, S., Barba, G. D., Thibaudet, M.C., Smagghe, A., Remy, P., \& Traykov, L.(2006). Executive function deficits in early Alzheimer's disease and their relations with episodic memory. Archives of Clinical Neuropsychology, 21(1), 15-21.

Beato, R. G., Nitrini, R., Formigoni, A. P., \& Caramelli, P. (2007). Brazilian version of the Frontal Assessment Battery (FAB): Preliminary data on administration to healthy elderly. Dementia \& Neuropsychologia, 1, 59-65.

Beato, R., Amaral-Carvalho, V., Guimarães, H. C., Tumas, V., Souza, C. P., Oliveira, M. N., \& Caramelli P. (2012). Frontal assessment battery in a Brazilian sample of healthy controls: Normative data. Arquivos de Neuropsiquiatria, 70(4), 278-280.

Boban, M., Malojcic, B., Mimica, N., Vukovic, S., \& Zrilic, I. (2012). The Frontal Assessment Battery in the differential diagnosis of dementia. Journal of Geriatric Psychiatry and Neurology, 25(4), 201-207.

Castiglioni, S., Pelati, O., Zuffi, M., Somalvico, F., Marino, L., Tentorio, T., \& Franceschi, M. (2006). The frontal assessment battery does not differentiate frontotemporal dementia from Alzheimer's disease.
Dementia and Geriatric Cognitive Disorders, 22(2): 125-131.

Cunha, P. J., Nicastri, S., Gomes, L. P., Moino, R. M., \& Peluso, M. A. (2004). Neuropsychological impairments in crack cocaine dependent inpatients: preliminary findings. Revista Brasileira de Psiquiatria, 26(2), 103-106.

Cunha, P. J., Nicastri, S, Andrade, A. G., \& Bolla, K. I. (2010). The frontal assessment battery (FAB) reveals neurocognitive dysfunction in substance-dependent individuals in distinct executive domains: Abstract reasoning, motor programming, and cognitive flexibility. Addictive Behavior, 35(10), 875-881.

de Paula, J. J., Ávila, R. T., Costa, D. S., Moras, E. N., Bicalho, M. A., Nicolato, R., Corrêa, H., Sedó, M., \& Malloy-Diniz, L. F. (2011). Assessing processing speed and executive functions in low educated older adults: The use of the five digit test in patients with Alzheimer's disease, Mild Cognitive Impairment and Major Depressive Disorder. Clinical Neuropsychiatry, 8(6), 339-246.

de Paula, J. J., Moreira, L., Nicolato, R., de Marco, L. A., Corrêa, H., Romano-Silva, M. A., Moraes, E. N., Bicalho, M. A., \& Malloy-Diniz, L. F. (2012a). The Tower of London Test: Different Scoring Criteria for diagnosing Alzheimer's disease and Mild Cognitive Impairment. Psychological Reports, 110(2), 477-488.

de Paula, J. J., Costa, D. S., Moraes, E. N., Nicolato, R., Sedó, M., \& Malloy-Diniz, L. F. (2012b). Automatic and Controlled Attentional Processes in Amnestic Mild Cognitive Impairment: The use of a Mini-Verbal Test. Psychology, 3(5), 379-383.

de Paula, J. J., \& Malloy-Diniz, L. F. (2013). Executive functions as predictors of functional performance in mild Alzheimer's dementia and Mild Cognitive Impairment elderly. Estudos de Psicologia (Natal), 18(1), 117-124.

de Paula, J. J., Miranda, D. M., Moraes, E. N., \& Malloy-Diniz, L. F. Mapping the clockworks: What does the Clock Drawing Test assess in normal and pathological aging? Arquivos de Neuropsiquiatria. (In press).

Dias, F. M. V., Doyle, F. C. P., Kummer, A., Cardoso, F., Caramelli, P., \& Teixeira, A. L. (2009). Executive functioning in patients with blepharospasm in 
comparison with patients with hemifacial spasm. Arquivos de Neuropsiquiatria, 67(1), 12-15.

Domingues, S. C. A., Mendonça, J. B., Laranjeira, R., \& Nakamura-Palacios, E. M. (2009). Drinking and driving: A decrease in executive frontal functions in young drivers with high blood alcohol concentration. Alcohol, 43, 657-664.

Dubois, B., Slachevsky, A., Litvan, I., \& Pillon, B. (2000). The FAB: A Frontal Assessment Battery at bedside. Neurology, 55, 1621-1626.

Fonseca, R. P., Parente, M. A. M. P., Côté, H., Ska, B., \& Joanette, Y. (2008). Introducting a communication assessment tool to Brazilian speech therapists: The MAC Battery. Pró-Fono, 20(4), 285-291.

Fontes, M. A., Bolla, K. I., Almeida, P. P., Jungerman, F., Laranjeira, R. R., Bressan, R. A., \& Lacerda, A. L. (2011). Frontal Assessment Battery (FAB) is as simple tool for detecting executive deficits in chronic cannabis users. Journal of Clinical and Experimental Neuropsychology, 33(5), 523-531.

Hayward, G., Goodwing, G. M., \& Harmer, C. J. (2004). The role of the anterior cingulate cortex in the counting stroop task. Experimental Brain Research, 154, 355-358.

Henry, J. D., Crawford, J. C., \& Phillips, L. H. (2004). Verbal fluency performance in dementia of the Alzheimer's type: A meta-analayis. Neuropsychologia, 42, 1212-1222.

Instituto Brasileiro de Geografia e Estatística IBGE (2002). Perfil dos idosos responsáveis pelos domicílios no Brasil. Acesso em 15 de maio de 2013, em http://www.ibge.gov. br/home/estatistica/populacao/perfilidoso/ default.shtm

Kim, T. H., Huh, Y., Choe, J. Y., Jeong, J. W., Park, J. H., Lee, S. B., Lee, J. J., Jhoo, J. H., Lee, D. Y., Woo, J. I., \& Kim, K. W. (2010). Korean Version of Frontal Assessment Battery: Psychometric Properties and Normative Data. Dementia and Geriatric Cognitive Disorders, 29(4), 636-670.

Kummer, A., Cardoso, F., \& Teixeira, A. L. (2009a). Suicidal ideation in Parkinson's Disease. CNSSpectrums, 14(8), 431-436.

Kummer, A., Cardoso, F., \& Teixeira, A. L. (2009b). Loss of libido in Parkinson's disease. The Journal of Sexual Medicine, 6(4), 1024-1031.

Kummer, A., Harsányi, E., Dias, F. M. V., Cardoso, F., Caramelli, P., \& Teixeira, A. L. (2009). Depression impairs executive functioning in Parkinson disease patients with low educational level. Cognitive and Behavioral Neurology, 22, 167-172.

Langenecker, S. A., Kennedy, S. E., Guidotti, L. M., Briceno, E. M., Own, L. S., Hooven, T., Young, E. A., Akil, H., Noll, D. C., \& Zubieta, J. K. (2007). Frontal and limbic activation during inhibitory control predicts treatment response in major depressive disorder. Biological Psychiatry, 62(11), 1272-1280.

Liscic, R. M., Storandt, M., Cairns, N. J., \& Morris, J. C. (2007). Clinical and psychometric distinction of frontotemporal and Alzheimer dementias. Archives of Neurology, 64(4), 535-540.

Luria, A. R. (1966). Higher Cortical Functions in Man. New York: Basic Books.

Machado, T. H., Fichman, H. C., Santos, E. L., Carvalho, V. A., Fialho, P. P., Koenig, A. M., Fernandes, C. S., Lourenço, R. A., Paradela, E. M. P., \& Caramelli, P. (2009). Normative data for healthy elderly on the phonemic verbal fluency task F.A.S. Dementia \& Neuropsychologia, 3(1), 55-60.

Malloy-Diniz, L. F., Leita, W. B., Moraes, P. H., Correa, H., Bechara, A., \& Fuentes, D. (2008). Brazilian Portuguese version of the Iowa Gambling Task: Transcultural adaptation and discriminant validity. Revista Brasileira de Psiquiatria, 30(2), 144-148.

McKhann, G., Drachman, D., Folstein, M., Katzman, R., Price, D., \& Stadlan, E. M. (1984). Clinical diagnosis of Alzheimer's Disease: Report of the NINCDS-ADRDA Work Group under the auspices of Department of Health and Human Services Task Force on Alzheimer's Disease. Neurology, 34, 939-944.

Moura, S. M., \& Haase, V. G. (2008). Características psicométricas e dados normativos do Teste das Três Palavras e Três Figuras (3P3F) no Brasil. Psico, 39(4), 500-508.

Nagata, T., Shinagawa, S., Ochiai, Y., Aoki, R., Kasahara, H., Nukariya, K., \& Nakayama, K. (2010). Association between executive dysfunction and hippocampal volume in Alzheimer's disease. International Psychogeriatrics, 23(5), 764-771.

Pedroso, R. V., Coelho, F. G., Santos-Galdurós, R. F., Costa, J. L., Gobbi, S., \& Stella, F. (2012). Balance, executive functions and falls in elderly with Alzheimer's disease (AD): A longitudinal study. Archives of Gerontology and Geriatrics, 54(2), 348-351. 
Portney, L. G., \& Watkins, M. P. (2000). Foundations of clinical research: Applications to practice. New Jersey: Prentice Hall.

Rodrigues, G. R., Souza, C. P., Cetlin, R. S., Oliveira, D. S., Pena-Pereira, M., Ujikawa, L. T., Marques Jr, W., \& Tumas, V. (2009). Use of the frontal assessment battery in evaluating executive dysfunction in patients with Huntington's disease. Journal of Neurology, 256, 1809-1815.

Román, G. C., Tatemichi, T. K., Erkinjuntti, T., Cummings, J. L., Masdeu, J. C., Garcia, J. H., Amaducci, L., Orgogozo, J. M., Brun, A., \& Hofman, A. (1993). Vascular dementia: diagnostic criteria for research studies. Report of the NINDSAIREN International Workshop.Neurology, 43(2), 250-260.

Salthouse, T. (2012). Consequences of Age-Related Cognitive Declines. Annual Reviews of Psychology, 63, 201-226.

Saur, R., Maier, C., Milian, M., Riedel, E., Berg, D., Liepelt-Scarfone, I., \& Leyhe, T. (2012). Clock test deficits related to the global cognitive state in Alzheimer's and Parkinson's disease. Dementia and Geriatric Cognitive Disorders, 33(1), 59-72.

Schroeter,M.L., Stein, T., Maslowski, N., \&Neumann, J. (2009). Neural correlates of Alzheimer's disease and mild cognitive impairment: A systematic and quantitative meta-analysis involving 1,351 patients. Neuroimage, 47(4), 1196-1206.

Slachevsky, A., Villalpando, J.M., Sarazin, M., HahnBarma, V., Pillon, B., \& Dubois, B. (2004). Frontal assessment battery and differential diagnosis of frontotemporal dementia and Alzheimer disease. Archives of Neurology, 61(7), 1104-1007.

Umetsu, A., Okuda, J., Fujii, T., Tsukiura, T., Nagasaka, T., Yanagawa, I., Sugiura, M., Inoue, K., Kawashima, R., Suzuki, K., Tabuchi, M., Murata, T., Mugikura, S., Higano, S., Takahashi, S., Fukuda, H., \& Yamadori A. (2002). Brain activation during the fist-edge-palm test: A functional MRI study. Neuroimage, 17(1), 385-392.

Wood, G. M. O., Carvalho, M. R. S., Neves, R. R., \& Haase, V. G. (2001). Validação da Bateria de Avaliação da Memória de Trabalho (BAMTUFMG). Psicologia: Reflexão e Crítica, 14(2), 325-341.
Yoon, C. W., Shin, J. S., Kim, H. J., Cho, H., Noh, Y., Kim, G. H., Chin, J. H., Oh, S. J., Kim, J. S., Choe, Y. S., Lee, K. H., Lee, J. H., Seo, S. W., $\& \mathrm{Na}, \mathrm{D}$. L. (2013). Cognitive deficits of pure subcortical vascular dementia vs Alzheimer disease: PiB-PET based study. Neurology, 80(6), 569-573.

Zago-Gomes, M. P., \& Nakamura-Palacios, E. M. (2009). Cognitive components of Frontal Lobe Function in Alcoholics Classified According to Lesch's Typology. Alcohol \& Alcoholism, 44(5), 449-457.

\section{Endereço para correspondência:}

Jonas Jardim de Paula

Instituto Nacional de Ciência e Tecnologia (INCT) de Medicina Molecular, Faculdade de Medicina, Universidade Federal de Minas Gerais

Av. Alfredo Balena, 190

CEP 30130-100 - Belo Horizonte/MG

E-mail: jonasjardim@gmail.com

Recebido em 18/02/2013

Revisto em 23/04/2013

Aceito em 30/04/2013

* Acknowledgments: grant INCT-MM (FAPEMIG: CBBAPQ-00075-09 / CNPq 573636/2008-2). 